\title{
The Ghanaian Manufacturing Sector 1991-1995: Firm Growth, Productivity and Convergence
}

\author{
Francis Teal
}

WPS/98-17

\author{
June 1998 \\ Centre for the Study of African Economies \\ Institute of Economics and Statistics \\ University of Oxford \\ St Cross Building \\ Manor Road \\ Oxford OX1 3UL
}

Key words: Ghana, productivity, manufacturing, human capital.

JEL categories: O12, O14, D24.

Correspondence to Dr F J Teal at the Centre for the Study of African Economies. Email address: francis.teal@economics.ox.ac.uk

Acknowledgements: The data used in this paper were collected over the period 1992 to 1996 by a team from the Centre for the Study of African Economies (CSAE), University of Oxford, the University of Ghana, Legon and the Ghana Statistical Office, Accra. The first three surveys, from 1992 to 1994, were part of the Regional Program on Enterprise Development (RPED) organised by the World Bank. The questionnaire was designed by a team from the World Bank. I am greatly indebted to officials at the Ghana Statistical Office for their assistance. The research was undertaken as part of the Trade and Enterprise Research Programme funded by the Department for International Development of the UK. The CSAE is funded by the Economic and Social Research Council of the UK.

\begin{abstract}
The removal of high levels of protection combined with substantial real devaluations has changed the environment in which Ghanaian manufacturing firms have operated in the 1990s. The changes in output, composition and productivity, which have occurred over this period, are examined in this paper. Survey evidence for the growth of the sector is shown to be consistent with data from sales tax returns. Analysis of the panel survey shows that, in a comparative context, the rate of job creation in Ghana's manufacturing sector is high. This rate is highest in medium sized firms; small firms have not grown more rapidly than larger firms. There has been no underlying growth in technical efficiency and output growth has been matched by a commensurate growth in labour and capital inputs. Labour productivity differs substantially by firm size due primarily to differences in physical, not human, capital endowments.
\end{abstract}





\section{Introduction}

The evidence seems very clear that the import substitution policies pursued from the 1960 s to the 1980s failed to provide the basis for the growth of the manufacturing sector in Africa, Riddell (1990). What is much less clear is what policies will provide the basis for the sustained growth of the sector. It is agued by Riddell that the problem lay not so much in the import substitution policies as in the failure to provide incentives for export. It is not the fact of protection, but the nature of the protection, that was the source of the policy failure. Many of the problems facing the sector have been identified as flowing from the extent and form of the protection. The use of quotas, rather than tariffs, ensured a lack of competition which was inimitable both to firm level efficiency and product quality. The administrative discretion which was attached to the quotas meant that large firms were favoured over smaller ones. The access of large firms to formal sector credit ensured an inappropriate degree of capital intensity in the context of credit rationing for smaller, more efficient, and competitive firms. The inability of small firms to expand, and the relative capital intensity of large firms, ensured a limited growth in labour demand with larger firms acting as a tax on consumers directly through high quota inclusive prices and indirectly though subsidies paid to many of these enterprises.

In Ghana the failure of policies of trade restrictions to promote the growth of the manufacturing sector is well documented. In the period 1971 to 1983 when aggregate real GDP fell by 30 per cent the share of manufacturing in GDP fell from 11 to 3 per cent, Rimmer (1992, p.160) and wages for workers in the manufacturing sector halved, Teal (1998). The period from 1983 to 1991 saw the sweeping away of nearly all trade restrictions. Quotas were abolished leaving protection effected by tariff rates which were generally low. The premium on foreign exchange was removed through substantial changes to the nominal exchange rate. In the first half of the 1990s the nominal exchange rate continued to fall effecting, over part of the period, a substantial real devaluation. The empirical question posed in this paper follows from this reversal of previous policies: have these reforms induced an expansion of the Ghanaian manufacturing sector and provided the basis for its sustained expansion? In answering that question the rate, and causes, of both output and productivity growth in Ghana's manufacturing sector over the period 1991 to 1995 will be examined.

The paper draws on a panel survey which enables the issues of firm productivity to be placed in the context of firm growth and enables answers to be given to a range of questions relating to the nature and causes of firm growth. How fast has been the growth of firms over the period? Have small firms grown relatively to large ones? Has growth occurred by increases in productivity, investment or by adopting increasingly labour intensive technologies? Does investment in human capital increase productivity and, if so, how much of the differences in productivity can be explained by human, relative to physical, capital? Do firms with more human capital grow faster or have faster rates of growth of productivity?

In the next section the methods that have been used to analyse firm growth are briefly reviewed. In section 3 three measures of firm growth, based on the survey data, are presented: growth in real value-added, employment and the real capital stock. How well the survey reflects outcomes at the sectoral level is assessed in section 4 by a comparison between the sales figures available from the survey and figures for total manufacturing sales from official sources. Both the survey and the official data suggest substantial growth. In section 5 we consider the evidence from the survey for the growth in productivity. In section 6 we consider the factors determining the growth of output and test formally if large firms, or ones in different sectors, or with differing levels of human capital, have grown more rapidly. A final section provides a summary and conclusions. 


\section{The Growth of Firms: the law of proportional effect}

Gibrat's law of proportional effect hypotheses that firm growth is independent of firm size. If this law were to hold the size distribution of firms would be characterised by a log normal distribution and the degree of firm concentration would grow over time. Prais (1976, p.29) shows that the use of this law can predict the growth in the degree of concentration in UK firms over the period 1910 to 1970. The model which has been the basis for tests of the applicability of Gibrat's law has been of the form,

$$
\Delta \mathrm{y}_{\mathrm{it}}=\beta \mathrm{y}_{\mathrm{i}(\mathrm{t}-1)}+\epsilon_{\mathrm{it}}
$$

where lower case letters denote logarithms.

The size distribution of firms that results depends on three parameters, $\beta$ in equation (1); the variance of the size distribution, $\sigma^{2}$ and the variance of the growth rates, $s^{2}$. These relationships are well known but it seems useful to set them out.

$$
\begin{aligned}
& y_{i t}=(\beta+1) y_{i(t-1)}+\epsilon_{i t} \\
& \sigma_{1}^{2}=(\beta+1)^{2} \sigma_{0}^{2}+s^{2}
\end{aligned}
$$

If $\beta$ is equal to zero then the variance of the size distribution necessarily rises over time. If $\beta$ is sufficiently less than zero then the variance may remain constant or fall over time. The sign, and significance, of $\beta$ has been the focus of attention in the convergence literature although this has not always been linked to the issue of the variance of the distribution.

If the variance is rising over time then the arithmetic mean of $Y$, denoted by $\alpha$, will be rising faster then the mean of the logarithm of $Y$, denoted by $\mu$. The relationship between the two is given by Aitchison and Brown (1956, p.8),

(4) $\alpha=\exp \left(\mu+\sigma^{2} / 2\right)$

(5) $\quad \mathrm{d} \alpha / \alpha=\mathrm{d} \mu+\sigma \mathrm{d} \sigma$

The early evidence suggested that $\beta=0$ might be a good approximation, at least for relatively large firms, Hart and Prais (1956). Recent evidence suggesting that the hypothesis fails for small firms can be found in Evans (1987a,b) and Hart and Oulton (1996). Prais (1976) shows that the hypothesis of $\beta=0$ is inconsistent with the fall in the level of concentration in UK manufacturing industry for the period from 1930 to 1950 . The more recent evidence seems to suggest strongly that small firms grow more rapidly then larger ones in both the UK and US. There is also evidence from manufacturing firms in Africa showing similar results, Mengistae (1996). Mead (1994) reports on the results of nationwide surveys of small enterprises in Botswana, Kenya, Malawi, Swaziland and Zimbabwe which find that most micro enterprises do not grow. ${ }^{1}$

Davis, Haltiwanger and Schuh (1996) argue that the finding that small firms grow faster than larger ones, based on regressions of the form of equation (1), are subject to bias in that a classification of firms by size includes firms with substantial negative transitory components.

${ }^{1}$ The survey results show that most micro enterprises are located in rural areas, whereas all the firms in the survey reported on in this paper are from urban localities. Other survey work showing small firm growth in Ghana is in Steel and Webster (1991). Lall, Navaretti, Teitel and Wignaraja (1994) use the first round of this survey to discuss the role of technology in the Ghanaian manufacturing sector. 
These small firms seem to grow faster as the negative transitory component is reversed over the period for which the growth rate is calculated. They show that the apparent negative relationship between firm size, as measured by employment, and growth can be removed by using a simple average of the plant's employment in the current and previous years. Indeed this calculation in their data, p.69, shows that net firm growth rises strongly with firm size. In terms of the regression equation (1) the bias results from measurement error in the lagged term which can, in principle, be allowed for by using instruments which are correlated with the level of output but not its growth rate.

\section{The Growth of Firms in Ghana: Evidence from the survey}

In this section the evidence from the survey for the growth of firms in Ghana's manufacturing sector will be presented. We begin with an examination of the process of job creation and destruction over time and ask if this process varies by the size category of the firms. The measurement concepts used are taken from Davis, Haltiwanger and Schuh (1996). They define gross job creation at time $t$ as equal to the employment gains summed over all plants that expand or start-up between (t-1) and t. The converse of this is gross job destruction which equals employment losses summed over all plants that contract or shut down between (t-1) and $t$. The net employment change at time $t$ is the difference between employment at time $t$ and employment at time (t-1). These definitions ensure that the net employment growth equals the job creation rate minus the job destruction rate. Two measures of firm size are used. In the top of Table 1 we use the simple average of the firm's employment in the current and previous year. In the bottom of Table 1 firms are classified by the size in the initial period. Four size classes are used, large which is firms with more than 100 employees, medium which is firms with from 30 to 99 employees, small which is 6 to 29 and micro which is firms with less than six employees.

Davis, Haltiwanger and Schuh (1996, p.21) provide an international comparison of the rates of job creation and destruction, mainly for developed economies. The finding, which is uniform across all the studies they review, is that net job growth is small relative to the gross rates of job creation and destruction. The unweighted averages for the rate of job creation is 12.2 per cent and for job destruction it is 11.9 per cent. In Ghanaian manufacturing the rate of job creation is very similar at 11.4 per cent. It is the rate of job destruction which is well below the average at 7.2 per cent. The rate of net employment growth in Ghana of 4.2 per cent is exceeded only by Morocco in the studies cited. It is clear from Table 1 that there is substantial variance across the four rounds of the survey. Gross job creation is highest in 1992/93 at 15.8 per cent and lowest in 1994/95 at 5.9 per cent. There is much less variation in the rate of gross job destruction. In Ghana, in common with all the other countries, the net rate of job creation is much below the gross rate. In a comparative context the rate of net job creation in Ghanaian manufacturing is high.

Do most jobs come from the small scale sector? If the calculation is done as in the bottom half of Table 1, in which firms are classified by their initial size, the answer would appear to be yes. However this is entirely the result of a the method of classification which Davis, Haltiwanger and Schuh (1996) argue to be inappropriate. The top half of the table shows that employment growth is remarkably uniform across the size spectrum. It is in fact highest for medium sized firm. The result here is identical to that in the Davis, Haltiwanger and Schuh (1996) comparison for US firms. They argue that it is myth that most jobs come from the small scale sector in the US. The same appears to be true in Ghana.

The results of Table 1 could be argued to show that firm growth, at least where size is measured by employment, is consistent with Gibrat's law. In the literature on firm growth various 
measures of firm size have been used. In Table 2 a sectoral breakdown is given for three measures of the growth of the firms in the survey: real value-added, labour and the real capital stock. While the survey was planned as a panel the number of firms for which there are complete observations for all five years is rather small. Rather than rely on this complete sample the growth rates are calculated from the maximum possible sample for the adjoint years. ${ }^{2}$ The figures given in Table 2 use the growth of the arithmetic mean for each of the four years to construct the profile of growth of the firms over the five year period. The results presented in Table 2 show that, for all firms, real value-added rose by 17 per cent over the five year period.

While for the average of all firms the growth in real value-added is in line with the growth of labour and capital inputs the same is not true for the sectoral components. Here there are very substantial differences across sectors. The garment and textile sector and sawmills both show very large growth of real value-added, 180 and 227 per cent respectively, with modest growth in inputs. In contrast the food sector saw a 50 per cent fall in real value-added with very large increases in inputs. Before considering how these sectoral results can be explained we first examine how consistent the average growth across the survey is with data collected at the level of aggregate manufacturing.

\section{The Growth of Firms in Ghana: Evidence from Sales Tax Returns}

Data from the Ghana Statistical Office has been used to provide estimates of firm sales based on the sales tax paid as collected by the Custom Excise and Prevention Service (CEPS). ${ }^{3}$ Table 3 provides a comparison of the figures from the CEPS source and the figures given by the Survey. From the CEPS data the implied increase in nominal sales values for firms in the manufacturing sector was 232 per cent over the period 1992 to 1995. Using the survey data, and confining the sample to those firms that paid sales tax in 1995, gives an increase in nominal value-added of 269 per cent, a higher figure than that from the CEPS data. Thus, where a direct comparison is possible, there is no evidence that the survey data are understating the growth in sales within the manufacturing sector. At the bottom of Table 3 the increase in the nominal value of sales from firms in the survey, for which we have information in both 1992 and 1995, is 205 per cent, which suggests that firms which are not paying sales tax are growing slower than those that are paying the tax.

The bottom half of Table 3 shows the growth of firm sales where the classification is by firm size. Larger firms defined in the Table as those with more than 65 employees had a rise in nominal sales values of 183 per cent; such firms paid 90 per cent of the sales tax recorded in the survey. Firms smaller than 65 employees grew much faster with a rise in nominal sales value from 1992 to 1995 of 296 per cent. Thus the data as presented in Table 3 suggests that smaller firms do grow substantially faster than larger ones where the size measure is sales. Such firms pay very little sales tax so, if the survey under-represents such firms, which is clearly the case, then the survey may be seriously underestimating the growth of firms in the manufacturing sector. We return to this issue below.

In Table 4 an attempt is made to provide a measure of the growth of the real value of sales from both the CEPS data and that from the survey. Over the period 1992 the nominal exchange rate rose faster than the CPI. We have chosen to take the average of the two as a best estimate of the rise in prices for the manufacturing sector. The CPI index will not fully capture the rise in

\footnotetext{
${ }^{2}$ The details of the calculation are given in Appendix Table 1.

${ }^{3}$ The data is presented in Amuzu (1997).
} 
traded goods prices implied by the change in the nominal exchange rate while the exchange rate index will overstate the raise in prices for the substantial part of the manufacturing sector which produces non-traded output. The result, shown in Table 4, is to suggest a rise in real sales from the CEPS data of 21 per cent over this period, or a rise of 6 per cent per annum. The figures from the survey data is 16 per cent, giving a rise of 5 per cent per annum. The rise in real sales being virtually identical to the rise in real value-added shown in Table 2. Either figures suggests strong growth, at lest by the standards of the pre-reform period. How has such growth been achieved?

\section{Productivity in Ghana's Manufacturing Sector}

The figures for firm growth presented in section 3 showed, for some sectors, substantially larger growth in value-added than in inputs. Does this imply that these sectors grew through rapid rises in productivity? To answer that question Table 5 presents an estimate of the production function characterising the Ghanaian manufacturing sector from the sample data. The production function we estimate is of the form:

$$
\mathrm{y}_{\mathrm{it}}=\alpha_{0}+\alpha_{1} \mathrm{k}_{\mathrm{it}}+\alpha_{2} \mathrm{l}_{\mathrm{it}}+\alpha_{3} \mathrm{~h}_{\mathrm{it}}+\text { sectoral controls }+ \text { ownership controls }+ \text { time dummies }
$$

where $\mathrm{y}$ is the $\log$ of real value-added, $\mathrm{k}$ is the $\log$ of the real physical capital stock, 1 is the $\log$ of employment and $\mathrm{h}$ is the log of human capital. ${ }^{4}$

There are a range of econometric problems associated with the estimation of equation (6). These include measurement errors, particularly in the capital stock series, and the presence of unobserved firm fixed effects, which, if correlated with the regressors, will induce bias in the estimates. The dataset we use is unusual in that it has measures of the skill composition of the firms. We can thus in the cross-section regressions control for a range of effects which might otherwise appear in the firm fixed effects. Human capital is measured by two variables. The first is the average years of education of workers in the firm, the second is the average length of their tenure in the firm. These can be thought of as proxying general and specific skills.

Table 5 shows the determinants of the log of real value-added per employee. Table 5 equation [1] shows the determinants of productivity, excluding the human capital terms. The log of employment tests for the existence of increasing or decreasing returns to scale. The sectoral variables enable differences in underlying technology across sectors to be identified and the time dummies capture any underlying shifts over time in the production function. Table 5, equation [2] extends the production function to include the two human capital variables. It will be noted that both the human capital variables are significant at the 5 per cent level or lower. However these variables do not change the productivity differentials across sectors. The omitted sector is metal working so the results from Table 5 show that there is broadly a high productivity area within manufacturing consisting of the food, sawmills and metal working sector and a low productivity area containing the furniture and garments sectors. The productivity differentials are large; furniture and garments are 50 per cent less productive than the other sectors within manufacturing. Finally in Table 5 we include a lagged dependent variable to test if the omission of dynamics from the other equations is biasing the results. While dynamics are important there are no significant changes to the long run estimates for the capital variables, although the standard errors on the human capital variables rise.

${ }^{4}$ Barr (1998) shows that a measure of social capital also affects the labour productivity of the firms. It is not included in this analysis as the measure is not available for all the years of the survey. 
It is true for the first two productivity equations presented in Table 5 that none of the time dummies are significantly different from zero. In equation [3] there is a significant negative coefficient for the final round. Interacting the time and sector dummies failed to produce any evidence for underlying technical progress for any of the sectors. Finally, it is necessary to note that the productivity equation is relatively well specified. The adjusted $\mathrm{R}^{2}$ is 0.42 and the standard error on the physical capital term is low in all the equations. While measurement error is likely to be serious it is not so serious that a production function cannot be identified from the data; the physical and human capital variables from the survey do explain a substantial part of the variation in productivity. What is their relative importance for explaining differences in labour productivity across the firms?

The results presented in Table 5 enable us to address the questions raised in the introduction as to the role of human capital in determining the productivity of firms in the Ghanaian manufacturing sector. In Table 6 we present the productivity and capital variables by firm size and by sector. Considering first the classification by size the data in Table 6 shows that virtually all the differences in labour productivity across firms of different size, that the equation can explain, is due to differences in physical capital per employee, the human capital variables play a small role. Moving from micro firms to large firms labour productivity rises by 240 per cent, capital per employee rises by 460 per cent, education by 23 per cent and tenure by 89 per cent. The rise in capital per employee is predicted to raise labour productivity by 106 per cent, while the education variable is predicted to raise it by less than 10 per cent and tenure by 20 per cent.

The two sectors which comprise the low productivity areas within manufacturing, garments and textiles and furniture are by far the most labour intensive sectors within the manufacturing sector. The capital labour ratios in both sectors are less than a third of the average. It is these two sectors where the use of apprenticeship labour is most pronounced. It is possible that the use of this labour, which is nominally undergoing training, may result in significantly lower levels of productivity for these two sectors. That is a matter, at present, for further research.

The implications for changes in productivity over time from Table 5 appear to be inconsistent with the data shown in Table 2 . The latter table seems to imply substantial sectoral differences in productivity growth, the former shows no change. As a first step to reconciling these differences we use the panel dimension of the survey to estimate a growth equation in the next section and assess if growth rates of real value-added or employment do differ by sector or by the size of the enterprise.

\section{Convergence in the Growth of Ghanaian Firms}

If we allow for fixed effects in (6) by differencing we implicitly produce a growth rate equation:

$$
\Delta \mathrm{y}_{\mathrm{it}}=\alpha_{0}+\alpha_{1} \Delta \mathrm{k}_{\mathrm{it}}+\alpha_{2} \Delta \mathrm{l}_{\mathrm{it}}+\alpha_{3} \Delta \mathrm{h}_{\mathrm{it}}+\mathrm{v}_{\mathrm{it}}
$$

In the literature examining the determinants of growth rates it has been a common practice to estimate the following equation:

$$
\Delta \mathrm{y}_{\mathrm{it}}=\alpha_{0}+\alpha_{1} \Delta \mathrm{k}_{\mathrm{it}}+\alpha_{2} \Delta \mathrm{l}_{\mathrm{it}}+\alpha_{3} \Delta \mathrm{h}_{\mathrm{it}}+\alpha_{4} \mathrm{y}_{\mathrm{i}(\mathrm{t}-1)}+\mathrm{v}_{\mathrm{it}}
$$

the term on $\mathrm{y}_{\mathrm{i}(\mathrm{t}-1)}$ is interpreted as testing for convergence. A negative coefficient implies that smaller firms grow more rapidly than large ones. One problem with such a specification is posed 
by measurement error which was discussed in section 2 . If the firms with low value-added in period t have a large negative error then the growth rate will be negatively correlated with the initial level. It was arguments of this form that led to the presentation of the data in Table 1 of firm growth where size was measured by the number of employees. In this section a formal test is conducted where the lagged value of real value-added is included in the regression and the variables determining the levels of this variable are used as instruments.

In Table 7 the results of estimating equation (7) and (8) are presented. Table 7 equation [1] shows the growth rate of real value-added as a function of the sectoral variables and time dummies. Equation [2] in the Table introduces the term in the lagged level of real value-added. In equation [3] this term is instrumented. In equation [1] there is no significant difference between the sectors in growth rates. The point estimates suggest that the metal working sector and sawmills grew faster than the other sectors but none of the sectoral dummy variables has a $t$ statistic greater than 0.6. In equation [2], which is of a form common in growth regressions, the lagged term in the log of real value-added is negative and highly significant. It appears to suggest that small firms do grow more rapidly than large ones where size is now measured by real valueadded. This is consistent with the findings presented in Table 3. The results in Table 7 equation [3] show that, once the lagged term is instrumented, both the point estimate and its significance declines. There is in equation [3] no evidence that small firms do grow faster than large ones. There is no evidence for any of the equations in Table 7 that there is any difference in sectoral growth rates.

The instruments used in Table 8 equation [3] are the levels of human capital in the firm. The Sargan test accepts the validity of these instruments. This implies that while the levels of human capital affect real value-added they do not affect its growth rate. The inclusion of the level variables in the growth rate equation supports that conclusion. There is therefore no evidence from the growth regressions that firms with higher levels of human capital grow more rapidly.

The implication of these results is that the findings in Table 2 of substantial differences in productivity growth across sectors may be due to the relatively small sample sizes and the substantial measurement error in the data. To assess that possibility Table 8 shows tests for convergence using employment as the measure of firms size. The equations in Table 8 seek confirmation of the result of Table 1 that firm growth, when measured by employment, is not related to firm size. In Table 8 three estimates of a growth equation are presented. The first uses only the data for which a complete sample is available over the period 1991 to 1995 . The annualised growth rate over that period is regressed on the log of the level of employment in 1991 and sectoral dummies. The result is a negative coefficient but, at the 5 per cent level, it is not significantly different from zero. As with real value-added there is no difference in the sectoral growth rates. In Table 8 equation [2] a similar regression to that reported in Table 7 is presented. The change in the log of employment is regressed on the lagged value of the log of employment. The result is a doubling of the coefficient to 0.04 and it is now significantly different from zero. Table 8 equation [3] allows for possible measurement error by instrumenting the variable. The point estimate for the coefficient is unchanged but it is no longer significantly different from zero. Once measurement error is allowed for there is, again, no evidence that firm growth rates are related to firm size.

In none of the regressions reported in Tables 7 and 8 do the sectoral growth rates, either of real value-added or employment, differ. The apparent finding in Table 2 of large differences in productivity growth across sectors is due to the small sample size and the consequent rise in standard errors with the fall in sample size. The regression results imply that these differences across sectors are not significant. There appears a remarkable uniformity across the whole of the 
Ghanaian manufacturing sector. Real value-added, employment and capital all grew by 4 per cent per annum on average over the period from 1991 to 1995.

\section{Summary and Conclusions}

The question which this paper has sought to address is how the economic reforms implemented in Ghana over the period from 1983 to 1991 have affected the expansion of its manufacturing sector in the first half of the 1990s. The issue is of importance for policy makers as the manufacturing sector is seen as having a key role in generating employment and more rapid growth at the macro level. The data used to address the issue was taken from a panel survey of Ghanaian manufacturing firms over the period 1991-1995. The survey data has been compared with aggregate data sources.

The survey data suggests that real value-added from the sector has grown by 17 per cent over the period 1991 to 1995, which implies an annual growth rate of 4 per cent. Data from sales tax returns gives a figure for the growth in the real value of sales, over this period, of 21 per cent. Where a direct comparison is possible, namely for those firms in the survey which pay sales tax, the sales growth figure from the survey is higher than that from the tax returns, Table 3 above. There are several factors that need to be considered in assessing whether the data from the survey is understating the growth of output. It seems likely that there will be a selectivity problem from the data for sales tax returns in that the more successful firms are the ones paying the tax. Such a selectivity problem would imply that the sales tax data was overstating the growth of output of the sector. However, if small firms, which generally do not pay sales tax, are growing more rapidly than larger firms the aggregate sales tax data will be understating the growth rate of the sector. If such an inverse relationship between firm growth and size exists then the size distribution in the sector may be converging. The issue of convergence is, therefore, linked with the question as to how far the survey data can be used as a basis for projecting the growth of the sector.

In assessing whether the survey data supports the hypothesis of convergence it is necessary to allow for measurement error. Two methods have been used in the paper to allow for such error. In Table 1 the rate of job creation and destruction in the economy was measured where size was the average across the two periods for which growth was measured. It was shown that if such a classification was chosen then there was no evidence that small firms grew faster than large ones. Indeed net job creation was largest for medium sized firms. In contrast, if firm were classified on the basis of initial employment there appears to be a strong inverse relationship between firm growth and firm size. The second method used to test for the importance of measurement error was to use instruments which were shown to be correlated with the level, but not the growth rate of the variable. Using real value-added as the size measure it was shown in Table 7 that a conventional test for convergence appeared to show that smaller firms grew faster than larger ones. However once the lagged term in the regression was instrumented there was no significant relationship between initial size and the growth rate. In Table 8 similar tests were carried out for firm growth using employment as the measure of size. The result here was less clear-cut than with real value-added but the hypothesis of independence of firm growth with size could be accepted. There is no evidence, once measurement error in the data is allowed for, that smaller firms in Ghana over this period have been growing faster than larger ones.

There is compelling evidence that the growth has occurred with no increases in productivity. In Table 5 regressions for productivity, measured as real value-added per employee, were presented. The first equation simply used a measure of physical capital. Human capital variables proxied by the average level of education and the average tenure of workers in the firm 
were then introduced and a lagged dependent variable was used to allow for adjustment lags. In none of the equations was there any evidence for a rise in underlying productivity over time. It was shown that nearly all of the differences across firms in labour productivity, which were very large, were explained by differences in physical, not human, capital endowments.

The inclusion of sectoral variables in a growth rate equation, Table 7, showed no evidence for differential rates of growth across sectors. Human capital variables in these equations were also not significant. On the basis of the survey data there is no evidence that sectoral growth rates differ or that human capital has had any impact on these growth rates. If growth rates do not differ by the size of firm, or by sector, then the figure for overall growth of 17 per cent is broadly consistent with the findings from the sales tax data. Substantial firm growth has occurred by increasing both labour and capital inputs with zero technical progress. 
Table 1 Job Creation and Destruction

Firms classified by the average of the two years of employment

$$
\text { 1991/92 1992/93 } \quad 1993 / 94
$$

1994/95 Average all

four periods

Large

$\begin{array}{llllll}\text { Creation } & 6.4 & 16.3 & 8.0 & 4.9 & 8.9 \\ \text { Destruction } & 9.4 & 1.9 & 2.9 & 6.0 & 5.1 \\ \text { Flow } & -3.0 & 14.4 & 5.1 & -1.1 & 3.8\end{array}$

Medium

$\begin{array}{llllll}\text { Creation } & 20.4 & 13.9 & 17.0 & 7.2 & 14.6 \\ \text { Destruction } & 4.6 & 14.1 & 12.9 & 3.6 & 8.8 \\ \text { Flow } & 15.8 & -0.2 & 4.1 & 3.6 & 5.8\end{array}$

Small

$\begin{array}{llllll}\text { Creation } & 22.0 & 17.1 & 12.2 & 10.9 & 15.6 \\ \text { Destruction } & 6.3 & 14.4 & 19.5 & 10.0 & 12.6 \\ \text { Flow } & 15.7 & 2.7 & -7.3 & 0.9 & 3.0\end{array}$

Micro

$\begin{array}{llllll}\text { Creation } & 32.6 & 26.9 & 17.4 & 4.2 & 20.3 \\ \text { Destruction } & 17.0 & 15.1 & 19.1 & 14.7 & 16.5 \\ \text { Flow } & 15.6 & 11.8 & -1.7 & -10.5 & 3.8\end{array}$

All Firms

$\begin{array}{llllll}\text { Creation } & 13.2 & 15.8 & 10.6 & 5.9 & 11.4 \\ \text { Destruction } & 7.7 & 7.7 & 7.4 & 6.1 & 7.2 \\ \text { Flow } & 5.5 & 8.1 & 3.2 & -0.2 & 4.2\end{array}$

Firms classified on the basis of initial employment Large

$\begin{array}{llllll}\text { Creation } & 6.3 & 16.6 & 8.2 & 4.9 & 9.0 \\ \text { Destruction } & 9.2 & 2.9 & 2.9 & 6.0 & 5.3 \\ \text { Flow } & -2.9 & 13.7 & 5.3 & -1.1 & 3.7\end{array}$

Medium

$\begin{array}{llllll}\text { Creation } & 18.4 & 13.2 & 10.9 & 6.9 & 12.4 \\ \text { Destruction } & 5.5 & 14.5 & 17.5 & 4.2 & 10.4 \\ \text { Flow } & 12.9 & -1.3 & -6.6 & 2.7 & 2.0\end{array}$

Small

$\begin{array}{llllll}\text { Creation } & 27.1 & 19.5 & 20.7 & 10.6 & 19.5 \\ \text { Destruction } & 6.6 & 11.7 & 12.9 & 9.7 & 10.2 \\ \text { Flow } & 20.5 & 7.8 & 7.8 & 0.9 & 9.3\end{array}$

Micro

$\begin{array}{llllll}\text { Creation } & 64.2 & 70.7 & 37.5 & 26.7 & 49.8 \\ \text { Destruction } & 7.1 & 12.1 & 5.0 & 2.2 & 6.6 \\ \text { Flow } & 57.1 & 58.6 & 32.5 & 24.4 & 43.2\end{array}$

All Firms

$\begin{array}{llllll}\text { Creation } & 13.5 & 16.5 & 10.8 & 5.9 & 11.7 \\ \text { Destruction } & 7.9 & 8.0 & 7.5 & 6.1 & 7.4 \\ \text { Flow } & 5.6 & 8.5 & 3.3 & -0.2 & 4.3\end{array}$


Table 2 Measures of the Growth of Firms (a)

$\begin{array}{llllll}1991 & 1992 & 1993 & 1994 & 1995 & 1991-95[\%]\end{array}$

Real Value-added (millions of 1991 cedis)

Food

73

78

70

44

$35-50$

Garments

4

5

11

9

180

and Textile

Furniture $\quad 22$

19

26

28

$24 \quad 8$

Sawmills $\quad 72$

121

172

356

$236 \quad 227$

Metal

46

58

72

62

$71 \quad 53$

Working

All firms

38

44

49

52

$45 \quad 17$

Employment (numbers of employees)

Food

28

35

37

39

$39 \quad 39$

Garments

17

17

16

$16 \quad 7$

and Textile

Furniture

43

46

50

47

$48 \quad 12$

Sawmills

162

123

126

155

$152-6$

Metal

50

56

57

56

$56 \quad 12$

Working

41

43

44

$44 \quad 16$

Real Capital Stock (millions of 1991 cedis)

Food

214

232

256

281

$283 \quad 32$

Garments

26

26

25

25

$25 \quad-4$

and Textile

Furniture $\quad 57$

56

59

60

$65 \quad 14$

Sawmills

662

648

647

665

$672 \quad 2$

Metal

165

163

169

169

1692

Working

All Firms

139

146

151

$153 \quad 13$

(a) Appendix Table 2 shows the deflators and methods used to calculate real value-added and the real capital stock. 
Table 3 Income from the Manufacturing Sector: a comparison of CEPS and GMES Data for 1992 and 1995

Source

1992

1995

Percentage

Increase

CEPS Income

$157,925,750,000$

$524,595,510,000$

232

RPED/GMES

If firm pays sales tax in 1995

Sales

$8,536,566,705$

$31,457,285,299$

269

Number of Firms

23

23

Employment

2832

3130

10.5

Sales Tax paid

$3,004,371,792$

10.5

Average sales tax rate (\%)

136

If firm does not pay sales tax in $\mathbf{1 9 9 5}$

Sales

$5,597,377,197$

Number of Firms

82

$12,501,914,035$

123

Employment

1908

82

2256

18.2

Sales Tax paid

Average employment size

23

0

28

RPED/GMES

If firm size is greater than 65 employees

Sales

$15,883,149,145$

$44,976,669,235$

183

Number of Firms

22

22

Employment

3885

4521

16.3

Sales Tax paid

$2,730,739,718$

Average sales tax rate (\%)

Average employment size

177

6

206

If firm size is less than $\mathbf{6 5}$ employees

$\begin{array}{ll}\text { Sales } & 3,744,839,825 \\ \text { Number of Firms } & 102 \\ \text { Employment } & 1862\end{array}$

$14,819,517,403$

296

102

1983

6.5

Sales Tax paid

$273,632,074$

Average sales tax rate (\%)

2

\section{All firms}

Sales

$19,627,988,970$

$59,796,186,638$

205

Number of firms

124

124

Employment

5747

6504

13.2

Sales Tax paid

$3,004,371,792$ 
Table 4 Income from the Manufacturing Sector: a comparison of CEPS and GMES Data for 1992 and 1995 in Nominal and Constant Prices

Source

1992

Nominal

CEPS Income

$157,925,750,000$

$524,595,510,000$

232

\section{RPED/GMES Sales}

1995

Percentage

Increase
Firms $>65$ employees

Firms $<65$ employees

All firms

(

$3,744,839,825$

$19,627,988,970$

National CPI $(1977=100)$

18,630

100

Cedis/US\$

437.09

100

Index of Cedis/US\$

100

$44,976,669,235183$

$14,819,517,403$

46,355

248.8

1200.43

274.6
$59,796,186,638$

183

296

205

148.8

174.6

Price Index which is the average of the CPI and Exchange Rate

100
161.7

\section{Real}

CEPS Income

$157,925,750,000$

$191,039,880,000$

21

RPED/GMES Sales

Firms $>65$ employees

$15,883,149,145$

$3,744,839,825$

$17,186,347,000$

8.2

Firms $<65$ employees

$19,627,988,970$

$5,662,788,000$

51.2

All firms

$22,849,135,000$

16.3 
Table 5 Productivity

Dependent variable: Log (Real Value-added/Employee)

\begin{tabular}{|c|c|c|c|}
\hline Constant & $\begin{array}{l}{[1]} \\
4.12 \\
{[9.3]^{* *}}\end{array}$ & $\begin{array}{l}{[2]} \\
3.41 \\
{[6.8]^{* *}}\end{array}$ & $\begin{array}{l}{[3]} \\
1.39 \\
{[2.8]^{* *}}\end{array}$ \\
\hline $\begin{array}{l}\text { Log (Real Value-added/ } \\
\text { employee })_{(t-1)}\end{array}$ & & & $\begin{array}{l}0.49 \\
{[9.0]^{* *}}\end{array}$ \\
\hline $\operatorname{Ln}(\mathrm{K} / \mathrm{L})_{(\mathrm{t}-1)}$ & $\begin{array}{l}0.26 \\
{[9.1]^{* *}}\end{array}$ & $\begin{array}{l}0.23 \\
{[6.7]^{* *}}\end{array}$ & $\begin{array}{l}0.13 \\
{[3.5]^{* *}}\end{array}$ \\
\hline $\operatorname{Ln}(\mathrm{L})_{(\mathrm{t}-1)}$ & $\begin{array}{l}0.08 \\
{[1.9]}\end{array}$ & $\begin{array}{l}0.04 \\
{[1.3]}\end{array}$ & $\begin{array}{l}0.01 \\
{[0.4]}\end{array}$ \\
\hline $\operatorname{Ln}(\text { Education })_{(t-1)}$ & & $\begin{array}{l}0.36 \\
{[2.3]^{*}}\end{array}$ & $\begin{array}{l}0.22 \\
{[1.5]}\end{array}$ \\
\hline $\operatorname{Ln}(\text { Tenure })_{(\mathrm{t}-1)}$ & & $\begin{array}{l}0.23 \\
{[3.1]^{* *}}\end{array}$ & $\begin{array}{l}0.08 \\
{[1.3]}\end{array}$ \\
\hline Food & $\begin{array}{l}0.20 \\
{[1.6]}\end{array}$ & $\begin{array}{l}-0.11 \\
{[0.9]}\end{array}$ & $\begin{array}{l}0.05 \\
{[0.4]}\end{array}$ \\
\hline $\begin{array}{l}\text { Garments } \\
\text { and Textile }\end{array}$ & $\begin{array}{l}-0.68 \\
{[5.6]^{* *}}\end{array}$ & $\begin{array}{l}-0.45 \\
{[3.1]^{* *}}\end{array}$ & $\begin{array}{l}-0.17 \\
{[1.4]}\end{array}$ \\
\hline Furniture & $\begin{array}{l}-0.48 \\
{[3.7]^{* *}}\end{array}$ & $\begin{array}{l}-0.40 \\
{[2.9]^{* *}}\end{array}$ & $\begin{array}{l}-0.18 \\
{[1.6]}\end{array}$ \\
\hline Sawmills & $\begin{array}{l}-0.04 \\
{[0.2]}\end{array}$ & $\begin{array}{l}0.09 \\
{[0.5]}\end{array}$ & $\begin{array}{l}0.05 \\
{[0.2]}\end{array}$ \\
\hline Round 3 & $\begin{array}{l}-0.05 \\
{[0.4]}\end{array}$ & $\begin{array}{l}-0.03 \\
{[0.2]}\end{array}$ & $\begin{array}{l}-0.18 \\
{[1.4]}\end{array}$ \\
\hline Round 4 & $\begin{array}{l}0.24 \\
{[1.9]}\end{array}$ & $\begin{array}{l}0.15 \\
{[1.2]}\end{array}$ & $\begin{array}{l}0.09 \\
{[0.8]}\end{array}$ \\
\hline Round 5 & $\begin{array}{l}0.07 \\
{[0.07]}\end{array}$ & $\begin{array}{l}-0.06 \\
{[0.5]}\end{array}$ & $\begin{array}{l}-0.24 \\
{[2.2]^{*}}\end{array}$ \\
\hline $\begin{array}{l}\mathrm{R}^{2} \\
\mathrm{~N} \\
\chi^{2} \text { (White test) (df) }\end{array}$ & $\begin{array}{l}0.42 \\
538 \\
91(90)\end{array}$ & $\begin{array}{l}0.42 \\
438 \\
136(123)\end{array}$ & $\begin{array}{l}0.58 \\
425 \\
127(157\end{array}$ \\
\hline $\begin{array}{l}\text { F test on Cobb-Douglas } \\
\text { specification } \\
\text { F test of interaction of } \\
\text { sectors with time dummies }\end{array}$ & $\begin{array}{l}0.32(3,520) \\
p=0.81 \\
0.66(12,503) \\
p=0.79\end{array}$ & $\begin{array}{l}1.2(10,411) \\
p=0.29 \\
0.71(12,401) \\
p=0.74\end{array}$ & \\
\hline
\end{tabular}

The figures in [ ] parentheses are $t$ ratios where the standard errors have been corrected by the method due to White (1980). 
* indicates significance at the 5 per cent level, ** indicates significance at the 1 per cent level. 
Table 6 Productivity Differences and Physical and Human Capital by Firm Size (Number of employees) and Sector

\begin{tabular}{|c|c|c|c|c|c|c|}
\hline & & $\begin{array}{l}\text { Value-added/ } \\
\text { Employee }\end{array}$ & $\begin{array}{l}\text { Capital/ } \\
\text { Employee }\end{array}$ & Education & Tenure & Size \\
\hline & & ('000 & & (Years) & (Years) & \\
\hline Size & & & & & & \\
\hline Large & Mean & 1,837 & 8,212 & 12.1 & 8.5 & 249 \\
\hline & Std & 2,679 & 25,111 & 1.6 & 4.8 & 146 \\
\hline & $\mathrm{N}$ & 77 & 77 & 73 & 73 & 77 \\
\hline Medium & Mean & 1,094 & 2,912 & 10.8 & 7.1 & 50 \\
\hline & Std & 1,863 & 4,824 & 2.5 & 5.3 & 16 \\
\hline & $\mathrm{N}$ & 122 & 122 & 116 & 116 & 122 \\
\hline Small & Mean & 537 & 925 & 9.9 & 4.7 & 14 \\
\hline & Std & 726 & 3,707 & 2.7 & 4.2 & 6 \\
\hline & $\mathrm{N}$ & 258 & 258 & 206 & 206 & 258 \\
\hline Micro & Mean & 541 & 1,457 & 9.8 & 4.5 & 4 \\
\hline & Std & 618 & 6,113 & 2.9 & 5.6 & 1 \\
\hline & $\mathrm{N}$ & 81 & 81 & 56 & 56 & 81 \\
\hline Sector & & & & & & \\
\hline Food & Mean & 1,149 & 3,392 & 10.3 & 6.6 & 56 \\
\hline & Std & 1,569 & 7,234 & 3.5 & 5.5 & 98 \\
\hline & $\mathrm{N}$ & 129 & 129 & 102 & 102 & 129 \\
\hline Garments and & Mean & 321 & 750 & 10.1 & 6.3 & 18 \\
\hline Textiles & Std & 451 & 2,661 & 1.6 & 5.7 & 16 \\
\hline & $\mathrm{N}$ & 124 & 124 & 74 & 74 & 124 \\
\hline Furniture & Mean & 453 & 654 & 10.4 & 4.7 & 55 \\
\hline & Std & 604 & 1,135 & 2.0 & 4.1 & 82 \\
\hline & $\mathrm{N}$ & 111 & 111 & 104 & 104 & 111 \\
\hline Sawmills & Mean & 1,772 & 13,790 & 11.7 & 5.9 & 183 \\
\hline & Std & 3,489 & 42,274 & 2.2 & 3.5 & 190 \\
\hline & $\mathrm{N}$ & 26 & 26 & 26 & 26 & 26 \\
\hline Metals & Mean & 1,169 & 2,584 & 10.6 & 6.1 & 61 \\
\hline & Std & 1,771 & 5,188 & 2.8 & 4.9 & 106 \\
\hline & $\mathrm{N}$ & 148 & 148 & 145 & 145 & 145 \\
\hline All Firms & Mean & 850 & 2,499 & 10.5 & 5.9 & 54 \\
\hline & Std & 1,523 & 10,616 & 2.6 & 5.0 & 98 \\
\hline & $\mathrm{N}$ & 538 & 538 & 451 & 451 & 538 \\
\hline
\end{tabular}


Std is the standard deviation, $\mathrm{N}$ is the number of observations. 
Table 7 Growth of Real Value-added

Dependent Variable ( $\Delta$ Real Value-added)

\begin{tabular}{|c|c|c|c|c|}
\hline & $\begin{array}{l}{[1]} \\
\text { OLS }\end{array}$ & $\begin{array}{l}{[2]} \\
\text { OLS }\end{array}$ & $\begin{array}{l}{[3]} \\
\text { IV (a) }\end{array}$ & $\begin{array}{l}{[4]} \\
\text { IV (b) }\end{array}$ \\
\hline Constant & $\begin{array}{l}-0.1 \\
{[0.8]}\end{array}$ & $\begin{array}{l}1.33 \\
{[3.7]}\end{array}$ & $\begin{array}{l}-0.05 \\
{[0.1]}\end{array}$ & $\begin{array}{l}-0.10 \\
{[0.12]}\end{array}$ \\
\hline $\begin{array}{l}\log (\text { Real Value- } \\
\text { added) } \\
(\mathrm{t}-1)\end{array}$ & & $\begin{array}{l}-0.13 \\
{[4.2]^{* *}}\end{array}$ & $\begin{array}{l}-0.004 \\
{[0.1]}\end{array}$ & \\
\hline$\Delta$ Physical Capital ${ }_{(\mathrm{t}-1)}$ & $\begin{array}{l}0.02 \\
{[0.1]}\end{array}$ & $\begin{array}{l}-0.10 \\
{[0.4]}\end{array}$ & $\begin{array}{l}0.01 \\
{[0.1]}\end{array}$ & $\begin{array}{l}0.03 \\
{[0.1]}\end{array}$ \\
\hline$\Delta$ Employment & $\begin{array}{l}0.71 \\
{[4.5]^{* *}}\end{array}$ & $\begin{array}{l}0.71 \\
{[4.6]^{* *}}\end{array}$ & $\begin{array}{l}0.71 \\
{[4.5]^{* *}}\end{array}$ & $\begin{array}{l}0.91 \\
{[1.9]}\end{array}$ \\
\hline$\Delta$ Human Capital $_{(\mathrm{t}-1)}$ & $\begin{array}{l}0.18 \\
{[0.9]}\end{array}$ & $\begin{array}{l}0.16 \\
{[0.8]}\end{array}$ & $\begin{array}{l}0.18 \\
{[0.9]}\end{array}$ & $\begin{array}{l}0.18 \\
{[0.9]}\end{array}$ \\
\hline Food & $\begin{array}{l}0.004 \\
{[0.03]}\end{array}$ & $\begin{array}{l}0.10 \\
{[0.7]}\end{array}$ & $\begin{array}{l}0.01 \\
{[0.1]}\end{array}$ & $\begin{array}{l}-0.002 \\
{[0.02]}\end{array}$ \\
\hline $\begin{array}{l}\text { Garments } \\
\text { and Textile }\end{array}$ & $\begin{array}{l}0.05 \\
{[0.3]}\end{array}$ & $\begin{array}{l}-0.05 \\
{[0.3]}\end{array}$ & $\begin{array}{l}0.05 \\
{[0.3]}\end{array}$ & $\begin{array}{l}0.03 \\
{[0.1]}\end{array}$ \\
\hline Furniture & $\begin{array}{l}0.13 \\
{[0.9]}\end{array}$ & $\begin{array}{l}0.10 \\
{[0.8]}\end{array}$ & $\begin{array}{l}0.13 \\
{[0.9]}\end{array}$ & $\begin{array}{l}0.13 \\
{[0.9]}\end{array}$ \\
\hline Sawmills & $\begin{array}{l}-0.23 \\
{[0.8]}\end{array}$ & $\begin{array}{l}0.09 \\
{[0.3]}\end{array}$ & $\begin{array}{l}-0.22 \\
{[0.7]}\end{array}$ & $\begin{array}{l}-0.25 \\
{[0.9]}\end{array}$ \\
\hline Round 4 & $\begin{array}{l}-0.12 \\
{[0.9]}\end{array}$ & $\begin{array}{l}-0.08 \\
{[0.7]}\end{array}$ & $\begin{array}{l}-0.12 \\
{[0.9]}\end{array}$ & $\begin{array}{l}-0.12 \\
{[0.9]}\end{array}$ \\
\hline Round 5 & $\begin{array}{l}0.31 \\
{[2.4]^{*}}\end{array}$ & $\begin{array}{l}0.31 \\
{[2.4]^{*}}\end{array}$ & $\begin{array}{l}0.31 \\
{[2.4]^{*}}\end{array}$ & $\begin{array}{l}0.32 \\
{[2.4]^{*}}\end{array}$ \\
\hline $\begin{array}{l}\text { Adjusted } \mathrm{R}^{2} \\
\mathrm{~N} \\
\chi^{2} \text { (White test) (df) } \\
\text { Sargan's F test for } \\
\text { instruments (df) } \\
\end{array}$ & $\begin{array}{l}0.08 \\
263 \\
72(73)\end{array}$ & $\begin{array}{l}0.14 \\
263 \\
107(87)\end{array}$ & $\begin{array}{l}0.21(3,246) \\
p=0.89\end{array}$ & $\begin{array}{l}0.15(3,247) \\
p=0.93\end{array}$ \\
\hline
\end{tabular}

(a) In this equation the term in Log (Real Value-added $)_{(t-1)}$ is instrumented with the log (Physical Capital) $)_{(t-}$

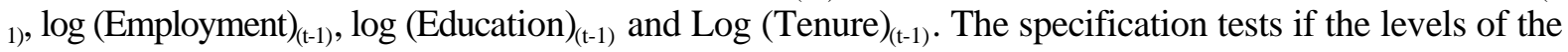
variables affect the growth rate and the acceptance of the Sargan test implies they do not.

(b) In this equation the term in $\log$ (Employment) is instrumented with the $\log$ (Physical Capital) $)_{(\mathrm{t}-1)}, \log$

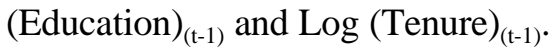


Table 8 Growth of Ghanaian Firms by Employment

Dependent Variable ( $\Delta$ Employment)

\begin{tabular}{|c|c|c|c|}
\hline & [1] & [2] & {$[3]$} \\
\hline & OLS (a) & OLS (b) & IV (b) (c) \\
\hline \multirow[t]{2}{*}{ Constant } & 0.10 & 0.12 & 0.11 \\
\hline & [2.8] & [1.7] & [0.9] \\
\hline \multirow[t]{2}{*}{ Employment $_{(\mathrm{t}-1)}$} & 0.02 & 0.04 & 0.04 \\
\hline & [1.9] & {$[2.0]^{*}$} & [0.9] \\
\hline \multirow[t]{2}{*}{ Food } & -0.02 & 0.05 & 0.05 \\
\hline & {$[0.5]$} & {$[0.8]$} & {$[0.7]$} \\
\hline \multirow{2}{*}{$\begin{array}{l}\text { Garments } \\
\text { and Textile }\end{array}$} & -0.04 & 0.12 & 0.11 \\
\hline & [1.1] & [1.7] & [1.7] \\
\hline \multirow[t]{2}{*}{ Furniture } & -0.01 & 0.04 & 0.03 \\
\hline & {$[0.3]$} & {$[0.7]$} & {$[0.6]$} \\
\hline \multirow[t]{2}{*}{ Sawmills } & -0.01 & 0.16 & 0.14 \\
\hline & {$[0.1]$} & [1.3] & [1.0] \\
\hline \multirow[t]{2}{*}{ Round 4} & & -0.04 & -0.03 \\
\hline & & {$[0.8]$} & {$[0.5]$} \\
\hline \multirow[t]{2}{*}{ Round 5} & & -0.03 & -0.03 \\
\hline & & {$[0.6]$} & {$[0.6]$} \\
\hline \multirow{4}{*}{$\begin{array}{l}\text { Adjusted } \mathrm{R}^{2} \\
\mathrm{~N} \\
\text { White } \chi^{2} \text { (df) } \\
\text { Sargan }\end{array}$} & -0.01 & 0.01 & -0.002 \\
\hline & 114 & 258 & 258 \\
\hline & & $34(37)$ & \\
\hline & & & $\begin{array}{l}0.15(1,245) \\
n=070\end{array}$ \\
\hline
\end{tabular}

(a) The dependent variable is the annualised logarithmic growth rate from 1991 to 1995 and the lagged employment variable is the log of employment in 1991.

(b) The dependent variables is the annual change in the log of employment and the lagged employment variable is the log of employment in the initial period.

(c)The instruments used for the lagged variable are the lagged log of education and the lagged log of tenure. 
Appendix Table 1 The Growth of Ghanaian Firms

\begin{tabular}{|c|c|c|c|c|c|}
\hline & $\mathrm{N}$ & $\begin{array}{l}1991-92 \\
105\end{array}$ & $\begin{array}{l}1992-93 \\
109\end{array}$ & $\begin{array}{l}1993-94 \\
117\end{array}$ & $\begin{array}{l}1994-95 \\
153\end{array}$ \\
\hline \multicolumn{6}{|l|}{ All firms: Value-added } \\
\hline \multirow{2}{*}{$\begin{array}{l}\text { Log of Value-added } \\
\text { in first period }\end{array}$} & Mean & 10.81 & 11.19 & 11.29 & 11.67 \\
\hline & Std & 2.0 & 1.93 & 2.11 & 2.06 \\
\hline \multirow{2}{*}{$\begin{array}{l}\text { Log of Value-added } \\
\text { in second period }\end{array}$} & Mean & 11.02 & 11.18 & 11.42 & 11.44 \\
\hline & Std & 2.0 & 2.01 & 2.02 & 2.17 \\
\hline \multirow{2}{*}{$\begin{array}{l}\text { Real Value-added in first } \\
\text { period ('00000 } 1991 \text { cedis) }\end{array}$} & Mean & 383 & 449 & 743 & 1,007 \\
\hline & Std & 139 & 149 & 206 & 3,711 \\
\hline \multirow{2}{*}{$\begin{array}{l}\text { Real Value-added in second } \\
\text { period ('00000 } 1991 \text { cedis) }\end{array}$} & Mean & 437 & 507 & 785 & 866 \\
\hline & Std & 147 & 146 & 291 & 2,796 \\
\hline \multicolumn{2}{|l|}{$\begin{array}{l}\text { Standard Deviation of Log } \\
\text { of Value-added in first period }\end{array}$} & 1.99 & 1.93 & 2.11 & 2.06 \\
\hline \multicolumn{2}{|l|}{$\Delta$ Mean of Log of Value-added } & 0.21 & -0.01 & 0.13 & -0.23 \\
\hline \multicolumn{2}{|l|}{$\Delta$ Mean of Value-added (percentage) } & 0.14 & 0.13 & 0.06 & -0.14 \\
\hline \multicolumn{2}{|l|}{$\begin{array}{l}\Delta \text { Standard Deviation } \\
\text { of the Size Distribution }\end{array}$} & 0.05 & 0.08 & -0.09 & 0.11 \\
\hline \multicolumn{6}{|l|}{ All firms: Employment } \\
\hline \multirow{2}{*}{$\begin{array}{l}\text { Log of Employment } \\
\text { in first period }\end{array}$} & Mean & 2.78 & 3.00 & 3.09 & 3.16 \\
\hline & Std & 1.24 & 1.19 & 1.33 & 1.33 \\
\hline \multirow{2}{*}{$\begin{array}{l}\text { Log of Employment } \\
\text { in second period }\end{array}$} & Mean & 2.93 & 3.03 & 3.07 & 3.16 \\
\hline & Std & 1.21 & 1.19 & 1.32 & 1.35 \\
\hline \multirow{2}{*}{$\begin{array}{l}\text { Employment in } \\
\text { first period }\end{array}$} & Mean & 38.1 & 42.4 & 56.9 & 60.7 \\
\hline & Std & 70.7 & 67.3 & 102.2 & 101.6 \\
\hline \multirow{2}{*}{$\begin{array}{l}\text { Employment in } \\
\text { second period }\end{array}$} & Mean & 41.2 & 44.2 & 58.2 & 61.1 \\
\hline & Std & 68.4 & 71.8 & 113.5 & 101.9 \\
\hline \multicolumn{2}{|l|}{$\begin{array}{l}\text { Standard Deviation of Log } \\
\text { of Employment in first period }\end{array}$} & 1.24 & 1.19 & 1.33 & 1.33 \\
\hline \multicolumn{2}{|l|}{$\Delta$ Mean of Log of Employment } & 0.15 & 0.03 & -0.02 & 0.00 \\
\hline \multicolumn{2}{|l|}{$\Delta$ Mean of Employment (percentage) } & 0.08 & 0.04 & 0.02 & 0.01 \\
\hline \multicolumn{2}{|l|}{$\begin{array}{l}\Delta \text { Standard Deviation } \\
\text { of the Size Distribution }\end{array}$} & -0.02 & 0.00 & -0.01 & 0.01 \\
\hline
\end{tabular}


$1991-92 \quad 1992-93 \quad 1993-94 \quad 1994-95$

All Firms: Real Physical Capital Stock

\begin{tabular}{|c|c|c|c|c|c|}
\hline $\begin{array}{l}\text { Log of Capital } \\
\text { in first period }\end{array}$ & $\begin{array}{l}\text { Mean } \\
\text { Std }\end{array}$ & $\begin{array}{l}15.35 \\
2.9\end{array}$ & $\begin{array}{l}15.55 \\
2.82\end{array}$ & $\begin{array}{l}15.58 \\
2.96\end{array}$ & $\begin{array}{l}15.91 \\
3.03\end{array}$ \\
\hline $\begin{array}{l}\text { Log of Capital } \\
\text { in second period }\end{array}$ & $\begin{array}{l}\text { Mean } \\
\text { Std }\end{array}$ & $\begin{array}{l}15.39 \\
2.9\end{array}$ & $\begin{array}{l}15.61 \\
2.81\end{array}$ & $\begin{array}{l}15.64 \\
2.95\end{array}$ & $\begin{array}{l}15.96 \\
3.03\end{array}$ \\
\hline $\begin{array}{l}\text { Capital in first period } \\
\text { (millions of } 1991 \text { cedis) Std }\end{array}$ & Mean & $\begin{array}{l}136 \\
458\end{array}$ & $\begin{array}{l}149 \\
501\end{array}$ & $\begin{array}{l}231 \\
953\end{array}$ & $\begin{array}{l}362 \\
1,629\end{array}$ \\
\hline $\begin{array}{l}\text { Capital in second period } \\
\text { (millions of } 1991 \text { cedis) Std }\end{array}$ & Mean & $\begin{array}{r}139 \\
491\end{array}$ & $\begin{array}{l}157 \\
551\end{array}$ & $\begin{array}{l}239 \\
958\end{array}$ & $\begin{array}{l}366 \\
1,606\end{array}$ \\
\hline $\begin{array}{l}\text { Standard Deviation of } \log \\
\text { of Capital in first period }\end{array}$ & & 2.9 & 2.82 & 2.96 & 3.03 \\
\hline$\Delta$ Mean of Log of Capital & & 0.04 & 0.06 & 0.06 & 0.05 \\
\hline$\Delta$ Mean of Capital (percentage) & & 0.02 & 0.05 & 0.03 & 0.01 \\
\hline $\begin{array}{l}\Delta \text { Standard Deviation } \\
\text { of the Size Distribution }\end{array}$ & & -0.02 & 0.0 & 0.0 & 0.0 \\
\hline
\end{tabular}

Notes: The increments of value-added, employment and capital in Table 2 are based on the data given here. The sample is confined to those firms for which information is complete in the adjoint years, ie for 1991 and 1992 there are 105 observations which increase to 153 for 1994 and 1995. A similar calculation is conducted by sector. 


\section{Appendix Table 2: Deflators for Real Value-added and Real Physical Capital Stock}

\begin{tabular}{|c|c|c|c|c|}
\hline & Food & $\begin{array}{l}\text { Clothing } \\
\text { and footwear }\end{array}$ & Furniture & CPI \\
\hline 1991 & 100.0 & 100.0 & 100.0 & 100.0 \\
\hline 1992 & 111.4 & 108.5 & 103.7 & 109.3 \\
\hline 1993 & 142.1 & 127.6 & 128.6 & 137.6 \\
\hline 1994 & 179.1 & 163.8 & 167.3 & 173.2 \\
\hline 1995 & 294.6 & 270.4 & 264.9 & 280.3 \\
\hline
\end{tabular}

if sector is foods then deflator= Food

if sector is garment or textile then deflator=Clothing and Footwear;

if sector $=$ furniture then deflator=Furniture

Other sectors use the CPI index.

The deflator used for the capital stock is a weighted average of the urban CPI (0.25) and the US\$ exchange rate $(0.75)$.

$\begin{array}{llll} & \text { CPI } & \text { Exchange Rate } & \text { Deflator } \\ 1990 & 83.99 & 88.7 & 99.1 \\ 1991 & 100 & 100 & 100 \\ 1992 & 109.3 & 118.8 & 116.4 \\ 1993 & 137.6 & 176.5 & 166.8 \\ 1994 & 173.2 & 260.1 & 238.4 \\ 1995 & 280.3 & 326.4 & 314.9\end{array}$

The Capital Stock Series are constructed as follows: it was assumed that the most recent data was the most reliable so the capital stock series for 1994 and 1994 were as reported in the questionnaire. A nominal series for earlier capital stocks (Capn) was then created by using the investment figures and revaluing the existing stock by the index. A constant price series (Capncp) was then calculated using a deflated value of the investment series, a rate of depreciation of 2 per cent was assumed. The following is the code used where cap5 and cap4 refers to the questionnaire data for waves 5 and 4 respectively

Capn5=cap5;

Capn4=cap4;

Capn3=(Capn4-invqu3 $)^{*} 166.8 / 238.4$;

Capn2 $=($ Capn3-invqu2 $) * 116.4 / 166.8$;

Capn1 $=($ Capn2-invqu1 $) * 100.0 / 116.4$;

Capn1cp=Capn1;

Capn2cp=Capn1+(invqu1)-0.02*Capn1;

Capn3cp=Capn2cp+(invqu2/1.164) $-0.02 *$ Capn2cp;

Capn4cp=Capn3cp+(invqu3/1.668)-0.02*Capn3cp;

Capn5cp=Capn4cp+(invqu4/2.384)-0.02*Capn4cp. 


\section{References}

J. Aitchison and J.A.C. Brown (1956) The Lognormal Distribution, Cambridge University Press. A. Amuzu (1997) Sources of Data on the Manufacturing Sector in Ghana's Economy, Ghana Statistical Office, mimeo, November.

A. Barr (1998) "Enterprise performance and the functional diversity of social capital", mimeo, CSAE, Oxford.

S. J. Davis, Haltiwanger, J.C. and S. Schuh (1996) Job Creation and Destruction, The MIT Press, Cambridge, Massachusetts.

D. S. Evans (1987a) "Tests of some alternative theories of firm growth", Journal of Political Economy, Vol. 95, pp.657-74.

D. S. Evans (1987b) "The relationship between firm growth, size and age: estimates for 100 manufacturing industries", Journal of Industrial Economics, Vol. 35, pp.567-81.

Gibrat, P. (1931) Les Inégalitiés Economiques. Paris: Sirey.

P.E. Hart and N. Oulton (1996) "Growth and size of firms", The Economic Journal, Vol. 106, No. 438, September, pp. 1242-1252.

P. E. Hart and S.J. Prais (1956) "The analysis of business concentration: a statistical approach", Journal of the Royal Economic Society, A, Vol. 119, pp.150-91.

Lall, S., Navaretti, G., Teitel, A. and Wignaraja, G. (1994) Technology and Enterprise Development: Ghana under Structural Adjustment, Macmillan.

Mead, D.C. (1994) "The contribution of small enterprises to employment growth in Southern and Eastern Africa", World Development, Vol. 22, No.12, pp.1881-1894.

T. Mengistae (1996) "Age-size effects in productive efficiency: a second test of the passive learning model”, CSAE Working Paper, WPS/96-2.

S.J. Prais (1976) The Evolution of Giant Firms in Britain, Cambridge University Press.

R.C. Ridell (1990) Manufacturing Africa, James Currey, London.

D. Rimmer (1992) Staying Poor: Ghana's Political Economy 1950-1990, Pergamon Press for the World Bank.

Steel, W.F. and Webster, L. (1991) Small Enterprises under Structural Adjustment in Ghana, World Bank Technical Paper Number 138, Industry and Finance Series.

F. Teal (1998) "Real Wages and the Demand for Skilled and Unskilled Male Labour in Ghana's Manufacturing Sector: 1991-1995", CSAE mimeo, March.

White, H. (1980) "A heteroscedasticity-consistent covariance matrix estimator and a direct test for heteroscedasticity", Econometrica, 48, 817-838. 